\title{
Lenograstim and filgrastim in the febrile neutropenia prophylaxis of hospitalized patients: efficacy and cost of the prophylaxis in a retrospective survey [Corrigendum]
}

Innocenti R, Rigacci L, Restelli U, et al. J Blood Med.

2019;10:21-27.

On page 24, Figure 2, the key for the figure was incorrect.

The corrected figure:

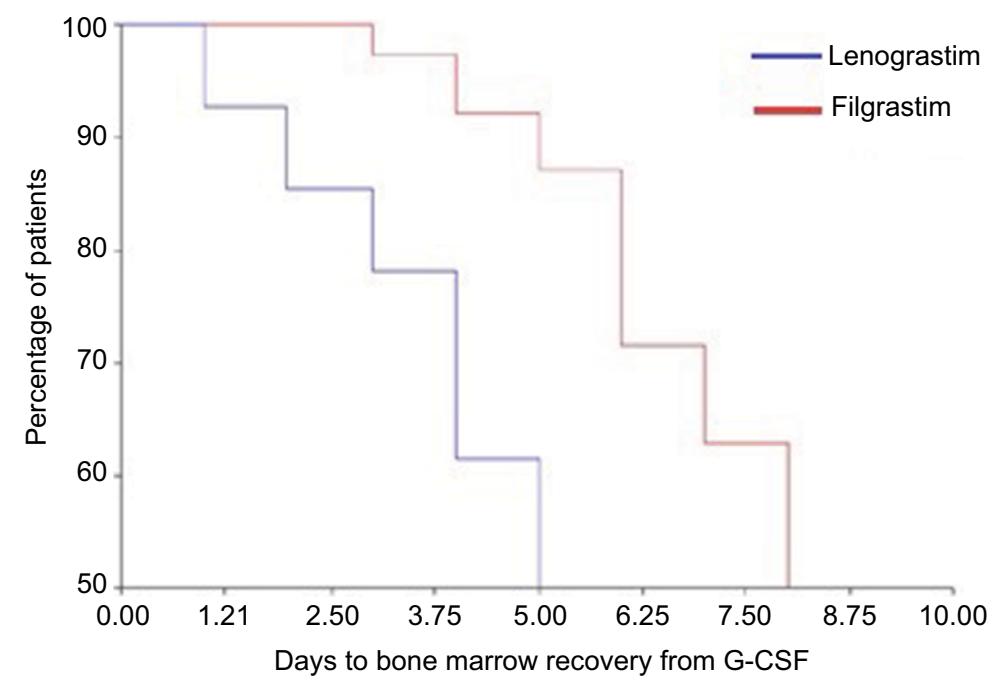

Figure 2 Kaplan-Meier plot of percentage of patients with bone marrow recovery at the time (days) of G-CSF discontinuation (lenograstim or filgrastim). Abbreviation: G-CSF, granulocyte-colony stimulating factor.

\section{Publish your work in this journal}

The Journal of Blood Medicine is an international, peer-reviewed, open access, online journal publishing laboratory, experimental and clinical aspects of all aspect pertaining to blood based medicine including but not limited to: Transfusion Medicine; Blood collection, Donor issues, Transmittable diseases, and Blood banking logistics; Immunohematology; Artificial and alternative blood based therapeutics; Hematology; Biotechnology/nanotechnology of blood related medicine; Legal aspects of blood medicine; Historical perspectives. The manuscript management system is completely online and includes a very quick and fair peer-review system. Visit http://www.dovepress.com/ testimonials.php to read real quotes from published authors. 